\section{The Effect of Temperature on Leaf and Flower Development and Flower Longevity of Zygopetalum Redvale 'Fire Kiss' Orchid}

\author{
Roberto G. Lopez ${ }^{1}$ and Erik S. Runkle ${ }^{2}$ \\ Department of Horticulture, Michigan State University, East Lansing, MI 48824
}

Additional index words. base temperature, degree-days, potted flowering orchids

\begin{abstract}
The vegetatively propagated 'Fire Kiss' clone of the hybrid Zygopetalum Redvale orchid has appealing potted-plant characteristics, including fragrant flowers that are waxy lime-green and dark maroon with a broad, three-lobed, magenta and white labellum. We performed experiments to quantify how temperature influenced leaf unfolding and expansion, time from visible inflorescence to flower, and longevity of individual flowers and inflorescences. Plants were grown in controlled-environment chambers with constant temperature setpoints of $14,17,20,23,26$, and $29^{\circ} \mathrm{C}$ and an irradiance of $150 \mu \mathrm{mol} \cdot \mathrm{m}^{-2} \cdot \mathrm{s}^{-1}$ for $9 \mathrm{~h} \cdot \mathrm{d}^{-1}$. As actual temperature increased from 14 to $25^{\circ} \mathrm{C}$, the time to produce one leaf decreased from 46 to 19 days. Individual plants were also transferred from a greenhouse to the chambers on the date that an inflorescence was first visible or the first flower of an inflorescence opened. Time from visible inflorescence to open flower decreased from 73 days at $14{ }^{\circ} \mathrm{C}$ to 30 days at $26{ }^{\circ} \mathrm{C}$. As temperature increased from 14 to $29{ }^{\circ} \mathrm{C}$, flower and inflorescence longevity decreased from 37 and 38 days to 13 and 15 days, respectively. Data were converted to rates, and thermal time models were developed to predict time to flower and senescence at different temperatures. The base temperature was estimated at $6.2{ }^{\circ} \mathrm{C}$ for leaf unfolding, $3.5^{\circ} \mathrm{C}$ for time to flower, and $3.7^{\circ} \mathrm{C}$ for flower longevity. These models could be used by greenhouse growers to more accurately schedule Zygopetalum flowering crops for particular market dates.
\end{abstract}

Potted flowering orchids are produced in large quantities throughout the world. For example, in 1995, the world demand for potted orchids was estimated at 1.22 billion units of plant stock (Hew and Yong, 1997). Orchids are the second most valuable flowering potted crop in the United States, with an estimated wholesale value in 2002 of approximately $\$ 105.6$ million (U.S. Department of Agriculture, 2003). However, environmental effects on growth and development of most orchid species are poorly understood, or not at all. Notable exceptions include some species and hybrids of Phalaenopsis, Cattleya, Cymbidium, and Dendrobium. In these genera, low temperature, short photoperiods, or both regulate the flowering process (Ichihashi, 1997; Rotor, 1952; Sakanishi et al., 1980).

Zygopetalum, or the ladybird orchid, is a sympodial terrestrial and epiphytic South American genus composed of 20 species (Rittershausen and Rittershausen, 2000). They are native to neotropic mountains $(1,300$ to $1,700 \mathrm{~m})$ of Brazil, Guiana, Venezuela, and Peru (Rose,

Received for publication 25 Feb. 2004. Accepted for publication 24 Apr. 2004. We gratefully acknowledge funding by Michigan's plant agriculture initiative at Michigan State University (Project GREEEN), the Michigan Agricultural Experiment Station, the Fred C. Gloeckner Foundation, and greenhouse growers providing support for Michigan State University floriculture research. We also thank Cathy Whitman for assistance with data collection.

${ }^{1}$ Graduate student.

${ }^{2}$ Assistant professor and extension specialist. To whom reprint requests should be addressed; e-mail runkleer@msu.edu.
1993). The hybrid Zygopetalum Redvale 'Fire Kiss' has attributes that make it an appealing potted plant. It is moderately compact ( 25 to $40 \mathrm{~cm}$ tall) and has exotic, waxy flowers with lime-green and dark-maroon sepals and petals, a broad magenta and white three-lobed labellum, and a strong, sweet, and spicy fragrance. Flowering of Zygopetalum is promoted by short days (SDs) followed by cool temperatures (e.g., 14 ${ }^{\circ} \mathrm{C}$ ), but the effects of temperature on growth and inflorescence development and longevity have not been determined (Lopez et al., 2003).

In the United States, potted flowering plants are commonly produced, marketed, and purchased for holidays such as Christmas, Valentine's Day, Easter, and Mother's Day. This requires an understanding of the flowering process so that greenhouse growers can schedule crops into flower for specific market dates. that are too immature (e.g., only flower buds) or are all open are often not sold or are sold for a lower price. Therefore, scheduling a crop of Zygopetalum to flower for a specific, predetermined market date has not been possible.

Temperature controls the rate of plant development, including time to unfold a leaf and time for an inflorescence to develop open flowers. Mathematical models have been developed to assist greenhouse growers with scheduling of flowering crops [e.g., Lilium longiflorum Thunb. (Fisher et al., 1996; Healy and Wilkins, 1984)]. Once plants have been grown at a variety of temperatures and time to reach a particular event (e.g., flowering) is quantified, data can be converted intorates. For example, the reciprocal Plants that do not have flowers or have flowers of days to flower becomes the rate of progress toward flowering. Developmental rate is zero at or below a species-specific base temperature $\left(\mathrm{T}_{\mathrm{b}}\right)$ and is maximum at the optimal temperature $\left(\mathrm{T}_{\text {opt }} ;\right.$ Roberts and Summerfield, 1987). Between $\mathrm{T}_{\mathrm{b}}$ and $\mathrm{T}_{\mathrm{opt}}$, rate of development is linear and can be described as

1/days $=b_{0}+b_{1} \mathrm{~T}$

where days is days to flowering, Tis temperature, and $b_{0}$ and $b_{1}$ are species-specific constants. The base temperature, $T_{b}$, can be calculated as

$\mathrm{T}_{\mathrm{b}}=-b_{0} / b_{1}$

Thermal time, or time to reach a particular developmental stage, can be quantified in degree-days $\left({ }^{\circ} \mathrm{C} \cdot \mathrm{d}^{-1}\right)$, which is calculated as

${ }^{\circ} \mathrm{C} \cdot \mathrm{d}^{-1}=1 / b_{1}$

Therefore, if the average daily temperature is $\mathrm{T}_{\mathrm{a}}$, the days necessary to complete a developmental process can be calculated by $\left({ }^{\circ} \mathrm{C} \cdot \mathrm{d}^{-1}\right) /\left(\mathrm{T}_{\mathrm{a}}-\mathrm{T}_{\mathrm{b}}\right)$.

In addition to time to flower, temperature also influences flower longevity of potted plants. For example, the overall flower longevity of potted Rhipsalidopsis gaertneri Reg. (Moran), an epiphyte with a geographic distribution similar to that of Zygopetalum, decreased from 43 to $26 \mathrm{~d}$ as temperature increased from 18 to $24{ }^{\circ} \mathrm{C}$ (Hartley et al., 1995). To maximize cut flower longevity, Cattleya, Cymbidium, and Dendrobium orchid flowers are often stored at 10 to $14{ }^{\circ} \mathrm{C}$; however, temperatures below this range can cause chilling injury (Sacalis, 1989, 1993).

Information on the time required to reach a developmental stage is critical to developing crop production schedules. The objectives of this study were to determine the relationship between temperature and 1) leaf unfolding rate (LUR) and expansion; 2) time from visible inflorescence to flower; and 3) flower and inflorescence longevity of Zygopetalum orchids.

\section{Materials and Methods}

Plant material. Vegetatively propagated 'Fire Kiss' clone of the hybrid Zygopetalum Redvale (Zygopetalum Artur Elle $\times$ Zygopetalum Titanic) plants were grown in a commercial greenhouse (Nurserymen's Exchange, Inc., Half Moon Bay, Calif.), transplanted into 38-cell plug trays in June 2000, and then into $10-\mathrm{cm}$ pots in April 2001. Plants were grown at 16 to $26{ }^{\circ} \mathrm{C}$ under natural photoperiods (lat. 37 ${ }^{\circ} \mathrm{N}$ ) with a maximum photosynthetic photon flux $(P P F)$ of $350 \mu \mathrm{mol} \cdot \mathrm{m}^{-2} \cdot \mathrm{s}^{-1}$. Five hundred plants in a fine-grade 4 fir bark : 1 perlite-based media were received in East Lansing, Mich., on 6 May 2001. They were maintained at $24 \pm 2$ ${ }^{\circ} \mathrm{C}$ in a glass-glazed greenhouse until experiments began. The photoperiod was a constant $16 \mathrm{~h}$ (0600 to $2200 \mathrm{HR})$, consisting of natural daylengths (lat. $42^{\circ} \mathrm{N}$ ) with day-extension lighting from high-pressure sodium (HPS) lamps, which delivered a supplemental $P P F$ of 20 to 35 $\mu \mathrm{mol} \cdot \mathrm{m}^{-2} \cdot \mathrm{s}^{-1}$ at plant height [as measured with 
Table 1. Actual average daily air temperatures of environmental chambers for each experiment.

\begin{tabular}{lccccccc}
\hline & & \multicolumn{5}{c}{ Air temp setpoint $\left({ }^{\circ} \mathrm{C}\right)$} \\
\cline { 3 - 7 } Experiment & Year & 14 & 17 & 20 & 23 & 26 & 29 \\
\hline 1 & 1 & 13.4 & 16.7 & 19.5 & 22.4 & 24.8 & 28.6 \\
& 2 & 13.4 & 17.3 & 19.5 & 22.4 & 25.5 & $--{ }^{\mathrm{z}}$ \\
2 & 1 & 13.5 & 17.4 & 19.5 & 22.0 & 25.5 & -- \\
& 2 & 12.2 & 17.6 & 21.1 & 23.5 & 25.7 & -- \\
3 & 1 & 13.4 & 17.1 & 19.5 & 25.9 & 25.4 & 28.6 \\
& 2 & 13.3 & 17.4 & 19.6 & 22.3 & 25.5 & -- \\
\hline
\end{tabular}

${ }^{\text {zTemperature not used. }}$

yPlants were grown in a greenhouse.

a line quantum sensor (Apogee Instruments, Inc., Logan, Utah)].

Plant culture. In Year 1, plants were fertilized at every irrigation using well water containing 95, 34, and $29 \mathrm{mg} \cdot \mathrm{L}^{-1} \mathrm{Ca}, \mathrm{Mg}$, and $\mathrm{S}$, respectively, supplemented with water-soluble fertilizer to provide the following $\left(\mathrm{mg} \cdot \mathrm{L}^{-1}\right)$ : $125 \mathrm{~N}, 12 \mathrm{P}, 125 \mathrm{~K}, 13 \mathrm{Ca}, 1.0 \mathrm{Fe}, 0.1 \mathrm{~B}$ and $\mathrm{Mo}$, and $0.5 \mathrm{Mn}, \mathrm{Zn}$, and $\mathrm{Cu}$ (MSU Special; Greencare Fertilizers, Chicago, Ill.). Water was acidified with $\mathrm{H}_{2} \mathrm{SO}_{4}$ to a titratable alkalinity of $\approx 140 \mathrm{mg} \cdot \mathrm{L}^{-1} \mathrm{CaCO}_{3}$. In Year 2, plants were irrigated as necessary with reverse osmosis water supplemented with water-soluble fertilizer to provide the following $\left(\mathrm{mg} \cdot \mathrm{L}^{-1}\right): 125 \mathrm{~N}, 12 \mathrm{P}$, $100 \mathrm{~K}, 65 \mathrm{Ca}, 12 \mathrm{Mg}, 1.0 \mathrm{Fe}$ and $\mathrm{Cu}, 0.5 \mathrm{Mn}$ and $\mathrm{Zn}, 0.3 \mathrm{~B}$, and $0.1 \mathrm{Mo}$.

Temperature and photoperiod control. All experiments were performed in walk-in controlled-environment chambers with constant temperature set points of 14, 17, 20, 23, and $26^{\circ} \mathrm{C}$. In Year 1 of Expts. 1 and 3 (see below), an additional chamber set at $29^{\circ} \mathrm{C}$ was used. In Expt. 1, Year 1 , the $23{ }^{\circ} \mathrm{C}$ treatment was provided in a greenhouse. Air temperature in each chamber was measured by an aspirated thermocouple every $10 \mathrm{~s}$ and hourly averages were recorded by a datalogger (CR-10; Campbell Scientific, Logan, Utah). The average daily air temperatures for all experiments were calculated (Table 1).

For Expt. 1, Year 1, each chamber was divided in half with black plastic, and two photoperiods were created: $9 \mathrm{~h}$ of light with or without a 4-h (2200 to $0200 \mathrm{HR}$ ) night interruption (NI). The 9-h SD base photoperiod was provided by a combination of cool-white fluorescent (VHOF96T12; Philips, Bloomfield, NJ) and incandescent lamps from 0800 to $1700 \mathrm{HR}$ at $150 \mu \mathrm{mol} \cdot \mathrm{m}^{-2} \cdot \mathrm{s}^{-1}$. NI lighting $\left(2\right.$ to $3 \mu \mathrm{mol} \cdot \mathrm{m}^{-2} \cdot \mathrm{s}^{-1}$ at canopy level) was provided by incandescent lamps. In Year 2, only a 9-h photoperiod was provided because photoperiod did not influence leaf development in Year 1.

Leafdevelopment (Expt.1). The experiment was replicated in time, beginning on 12 June 2001 (Year 1) and 19 Feb. 2002 (Year 2). Experimental treatments were identical between years, unless otherwise noted. Ten plants were assigned randomly to each of the SD and NI sections of the walk-in controlled-environment chamber. At the beginning of the experiment, one immature pseudobulb was identified and leaf unfolding was recorded weekly by counting the number of leaves from the top of the medium to the terminal end of the pseudobulb. A new leaf was counted as it became visible at the apex. The leaf length of a marked immature leaf was measured weekly (measured the incremental increase in leaf expansion was calculated. Plants were grown for 20 weeks, except for those at $29^{\circ} \mathrm{C}$, in which observations were terminated after 13 weeks because of declining growth and plant mortality.

Flower development (Expt. 2). The experiment was replicated in time, beginning on 12 Apr. 2002 (Year 1) and 19 Mar. 2003 (Year 2 ), with 10 plants per treatment. Plants were grown in a glass greenhouse, and on the date at which the first inflorescence was visible (visible from the medium surface to the leaf tip) and analysis is presented in Table 2. inflorescence, or VI) without dissection $(<1 \mathrm{~cm}$ long), plants were transferred to one of the five growth chambers until 10 plants were in each chamber. The date each plant was placed in the chamber and the date the first and subsequent flowers opened were recorded for each plant. At flowering, the number of flower buds and nodes on immature pseudobulbs below the inflorescence were counted and inflorescence length was measured. Days to flower and air temperature during that period were calculated for each plant.

Flower and inflorescence longevity (Expt. $3)$. The experiment was replicated in time, beginning on 8 Aug. 2001 (Year 1) and 14 Feb. 2002 (Year 2). Plants were grown in a glass greenhouse, and on the date that the first flower of an inflorescence opened on each plant, it was transferred to one of the growth chambers. The date that each plant was placed in a chamber and the date of flower mortality (senescence) of the first and subsequent flowers were recorded for each plant. The date of flower senescence was defined as the day that half of the labellum

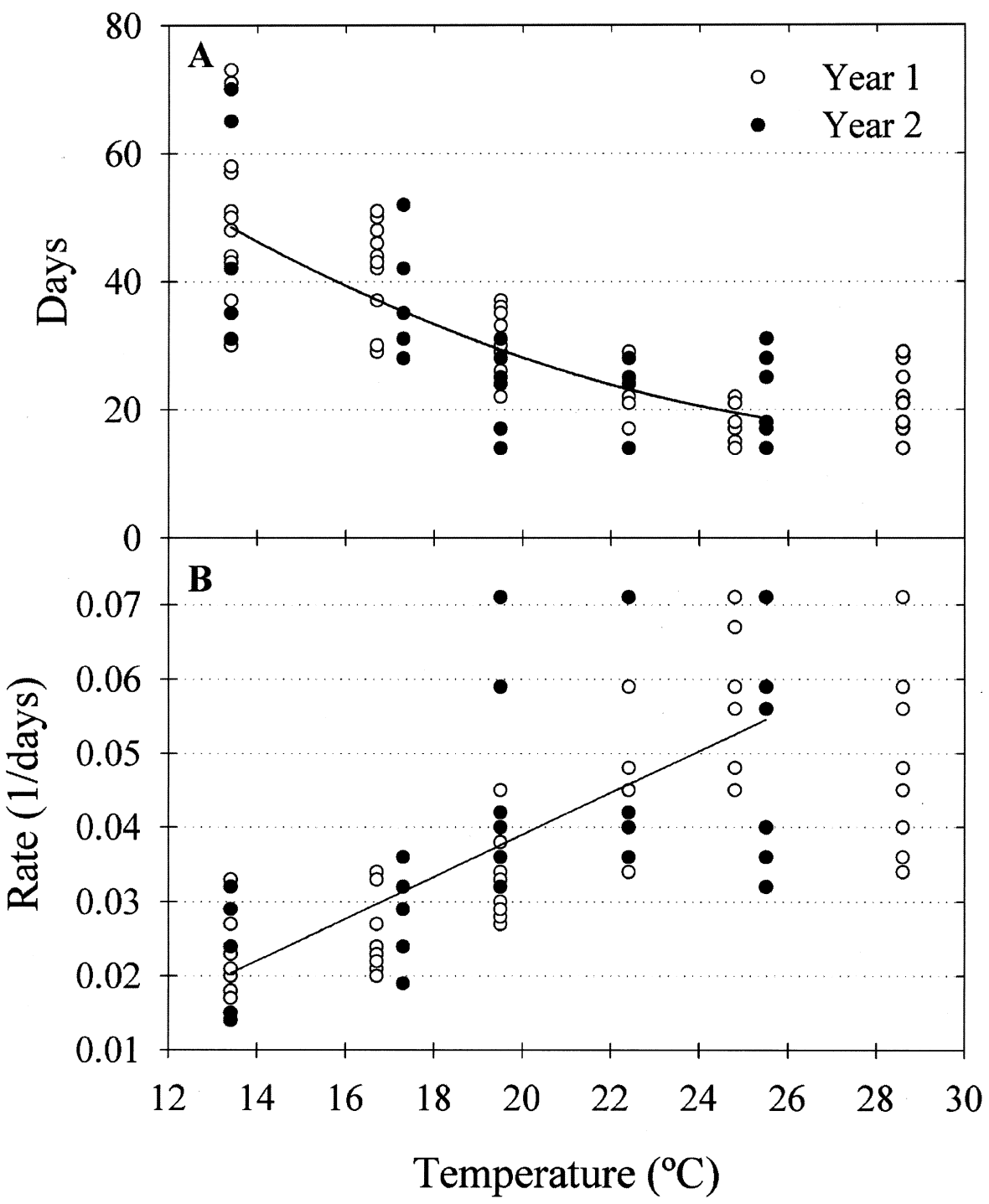

Fig. 1. Influence of forcing temperature on individual leaf unfolding of Zygopetalum Redvale 'Fire Kiss'. Each symbol represents an individual plant. The solid lines represent the regression equations using pooled data for Years 1 and 2. Data at $28.6^{\circ} \mathrm{C}$ were not included in the regression equation. Statistical 
Table 2. Parameters of linear regression analysis relating temperature to rate of progress for leaf development, time from visible inflorescence to flower, flower longevity of the first flower, and inflorescence longevity in Zygopetalum Redvale 'Fire Kiss'.

\begin{tabular}{lccccc}
\hline $\begin{array}{l}\text { Developmental } \\
\text { stage }\end{array}$ & $\begin{array}{c}\text { Intercept }\left(\mathrm{b}_{0}\right) \\
(1 / \text { days })\end{array}$ & $\begin{array}{c}\text { Slope }\left(\mathrm{b}_{1}\right) \\
(1 / \text { days }) /{ }^{\circ} \mathrm{C}\end{array}$ & $\mathrm{T}_{\mathrm{b}}\left({ }^{\circ} \mathrm{C}\right)$ & ${ }^{\circ} \mathrm{C} \cdot \mathrm{d}^{-1}$ & $r^{2}$ \\
\hline Leaf unfolding & $-0.0174 \pm 0.0038^{\mathrm{y}}$ & $0.0028 \pm 0.0002$ & 6.2 & 357 & $0.60^{* * *}$ \\
Visible inflorescence to flower & $-0.0053 \pm 0.0016$ & $0.0015 \pm 0.0001$ & 3.5 & 667 & $0.89^{* * * *}$ \\
Longevity of first flower & $-0.0100 \pm 0.0047$ & $0.0027 \pm 0.0002$ & 3.7 & 370 & $0.66^{* * * *}$ \\
Inflorescence longevity & $-0.0094 \pm 0.0042$ & $0.0026 \pm 0.0002$ & 3.6 & 385 & $0.69^{* * * *}$ \\
\hline
\end{tabular}

${ }^{2}$ The intercept and slope were used in Eqs. [1] and [2] to calculate base temperature $\left(\mathrm{T}_{\mathrm{b}}\right)$ and thermal time to complete a particular developmental stage $\left({ }^{\circ} \mathrm{C} \cdot \mathrm{d}^{-1}\right)$.

${ }^{y}$ Standard error.

**** Significant at $P \leq 0.001$.

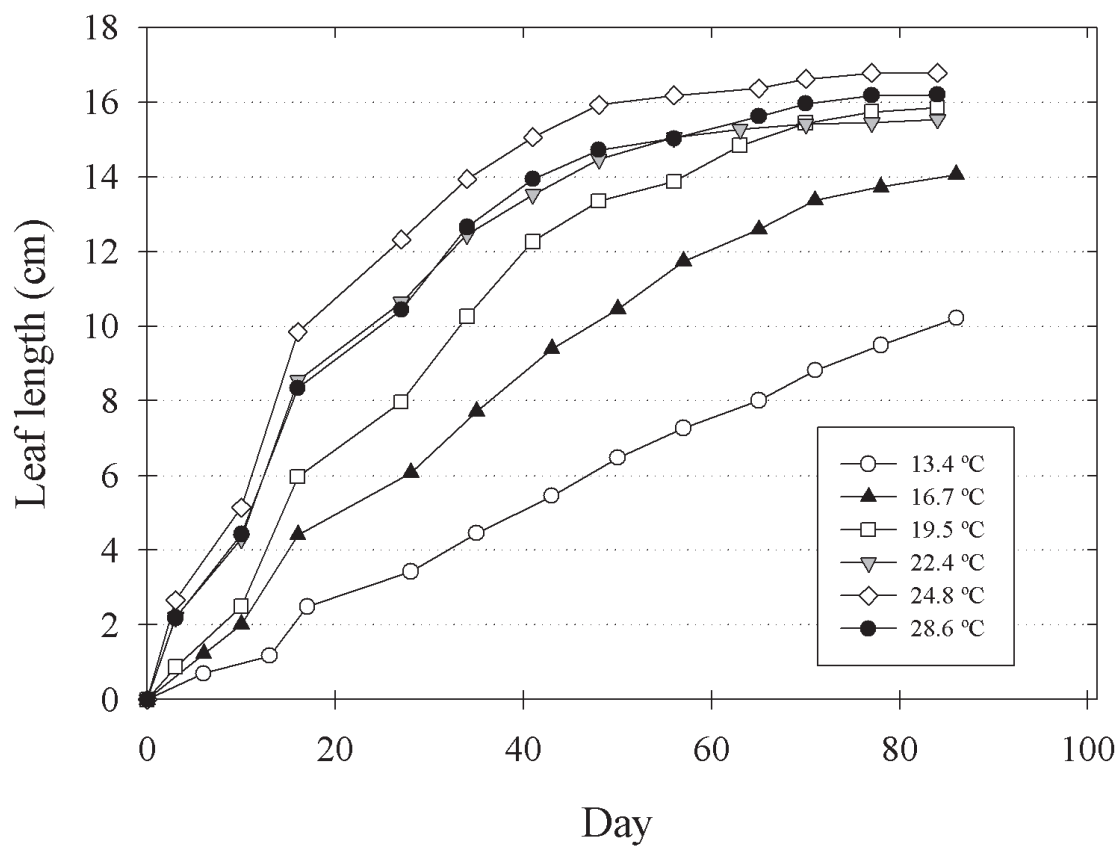

Fig. 2. Influence of forcing temperature on increase in leaf length (measured from the medium surface to the leaf tip) in Zygopetalum Redvale 'Fire Kiss'. Each symbol represents the average of 20 plants.

was discolored or wilted. Individual flower and inflorescence longevity was calculated for each plant at each temperature.

Data analysis. Each year, a completely randomized block design was used. Data were analyzed using SAS (SAS Institute, Cary, N.C.) mixed model procedure (PROC MIXED) for analysis of variance and linear models procedure (PROC REG) for regression models. Data were pooled in each experiment for all measured characteristics. The mean time to flower, LUR, and flower and inflorescence longevity at each temperature were converted to rates by taking the reciprocal (1/days). The relationship between rate of progress to flowering, leaf development or flower senescence (1/days) and mean temperature $T$ in ${ }^{\circ} \mathrm{C}$ were determined by Eqs. [1], [2], and [3] to calculate $\mathrm{T}_{\mathrm{b}}$ and ${ }^{\circ} \mathrm{C} \cdot \mathrm{d}^{-1}$. Within each developmental stage, slopes and intercepts were computed.

\section{Results}

Leaf development (Expt. 1). Photoperiod had no significant effect on leaf unfolding or leaf expansion, and thus data for both photoperiods were pooled. Time to unfold one leaf decreased as temperature increased, until it reached a minimum at $\approx 25{ }^{\circ} \mathrm{C}$ (Fig. 1). The varied among the temperature treatments ( 26 to $37 \mathrm{~cm}$ ), however no significant trends existed (data not presented).

Flower and inflorescence longevity. As temperature increased from 14 to $29^{\circ} \mathrm{C}$, longevity of the first open flower decreased from $37 \mathrm{~d}$ to $13 \mathrm{~d}$ (Fig. 4). Inflorescence longevity followed a similar pattern, decreasing from $38 \mathrm{~d}$ at 14 ${ }^{\circ} \mathrm{C}$ to $15 \mathrm{~d}$ at $29{ }^{\circ} \mathrm{C}$. Flower longevity of the second and subsequent flowers decreased by 1 to $3 \mathrm{~d}$ in comparison to the longevity of the first open flower at all temperatures studied (data not presented).

Flower and inflorescence longevity data were converted to rates, and a thermal time model was developed to predict senescence at different temperatures. Rate of progress to senescence of individual flowers and inflorescences was linear within the range of temperatures tested (Table 2). The base temperatures were estimated at 3.7 and $3.6^{\circ} \mathrm{C}$, and the accumulated thermal time lifespan was 370 and $385^{\circ} \mathrm{C} \cdot \mathrm{d}^{-1}$, respectively.

\section{Discussion}

As temperature increased from 14 to 26 ${ }^{\circ} \mathrm{C}$, the developmental rate at various stages of growth and development of Zygopetalum increased. Increasing temperature from 14 to $25{ }^{\circ} \mathrm{C}$ hastened leaf unfolding and expansion, accelerated time from VI to flower, and reduced the longevity of open flowers and inflorescences. Temperatures $>25{ }^{\circ} \mathrm{C}$ were generally superoptimal. For example, some flower buds of plants grown at the warmest temperatures developed necrotic lesions and aborted within 20 d. In addition, leaf development (unfolding and expansion) was maximal around $25^{\circ} \mathrm{C}$ and was retarded when the constant daily temperature was greater. Therefore, the optimal temperature for most rapid growth and development of Zygopetalum appears to be about $25^{\circ} \mathrm{C}$. The calculated base temperature of Zygopetalum was also similar among developmental phases and was between 3.5 and $6.2^{\circ} \mathrm{C}$.

A similar response to temperature has been observed in Phalaenopsis orchid. As temperature increased from 14 to $26^{\circ} \mathrm{C}$, the rate of leaf, bud, and flower development increased linearly in several hybrids (Robinson, 2002). The optimal temperature for growth of Phalaenopsis, which is native to tropical and subtropical areas of the South Pacific Islands and Asia, appeared to be $26{ }^{\circ} \mathrm{C}$ (Robinson, 2002). The calculated base temperature of Phalaenopsis was between 8 and $12^{\circ} \mathrm{C}$, which is 4 to $6^{\circ} \mathrm{C}$ higher than that reported here for Zygopetalum. This is not surprising, because Zygopetalum species are native to neotropic mid-elevation mountains (1,300 to $1,700 \mathrm{~m})$ that have moderate climates (Rose, 1993).

Leaf development and flower longevity were modeled as a function of temperature and were found to accurately predict the time of these developmental processes. To complete a developmental process, a plant must experience a specific number of units of degree-days (or thermal time) above the base temperature characteristic of that process (Roberts and Summerfield, 1987). For example, the model predicted 


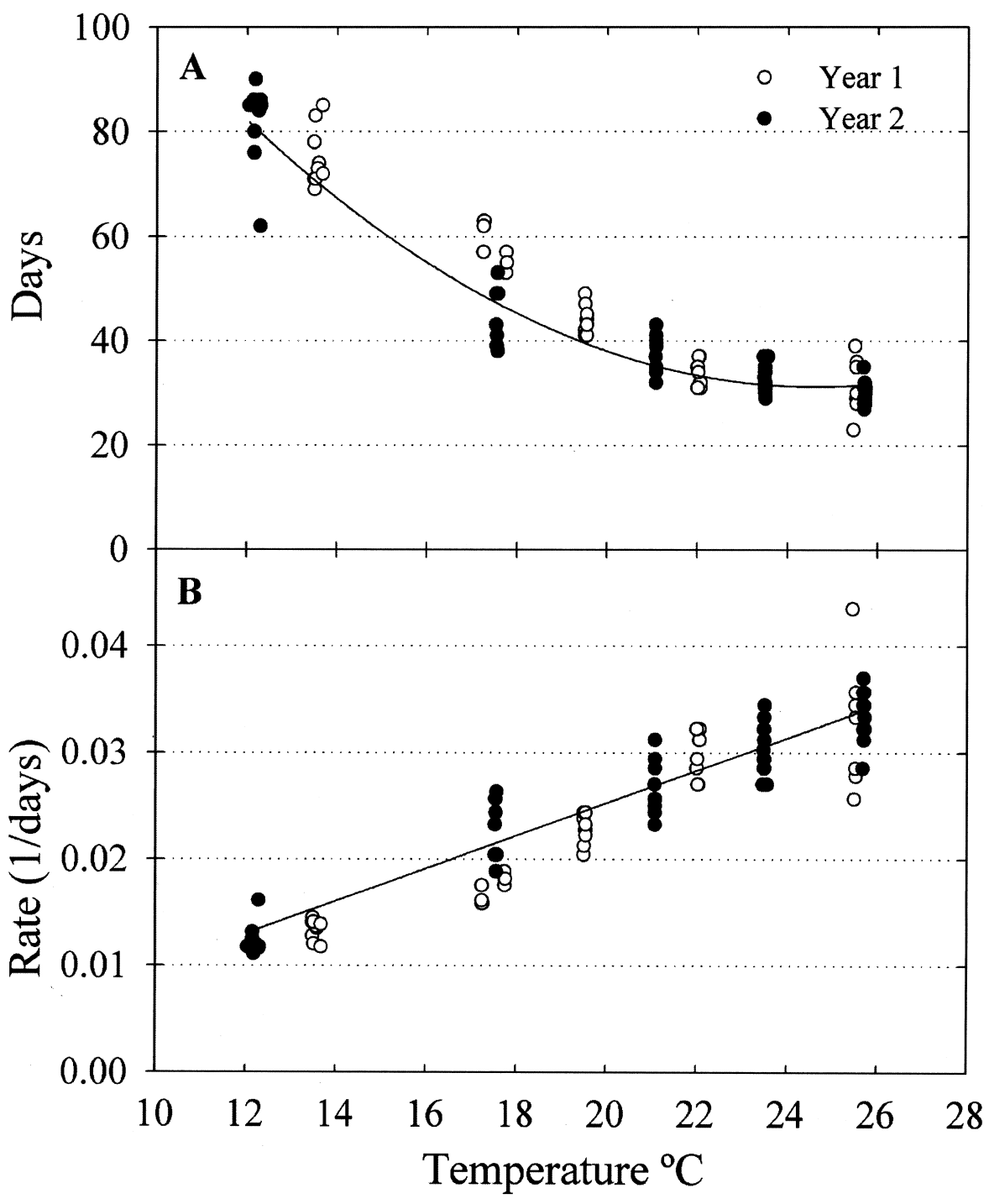

Fig. 3. Influence of forcing temperature on time from visible inflorescence (VI) to flower in Zygopetalum Redvale 'Fire Kiss'. Each symbol represents an individual plant. (A) Days from VI to flower. The solid line represents the regression equation using pooled data for Years 1 and 2. The line in (B) represents predicted values for the rate of progress (1/days) to flowering according to linear regression. Statistical analysis is presented in Table 2 .

that time from VI to flower for Zygopetalum grown at $26.0^{\circ} \mathrm{C}\left(\mathrm{T}_{\mathrm{b}}=3.5^{\circ} \mathrm{C}\right)$ is estimated at $667^{\circ} \mathrm{C} \cdot \mathrm{d}^{-1} /\left(26.0 \pm 3.5^{\circ} \mathrm{C}\right)=30 \mathrm{~d}$.

Actual time from VI to flower for plants forced at $26{ }^{\circ} \mathrm{C}$ was $30 \mathrm{~d}$. Flower longevity was also accurately predicted by our model; plants grown at $14{ }^{\circ} \mathrm{C}\left(\mathrm{T}_{\mathrm{b}}=3.7^{\circ} \mathrm{C}\right)$ had an estimated accumulated thermal time lifespan of $\left(370{ }^{\circ} \mathrm{C} \cdot \mathrm{d}^{-1} / 10.3{ }^{\circ} \mathrm{C}\right)=36 \mathrm{~d}$. Actual flower longevity observed was $37 \mathrm{~d}$. Therefore, these models could be used by greenhouse growers to coordinate flowering with specific market dates and to maximize flower longevity.

Thermal time models can also be used to maximize the flower life of potted flowering plants. Providing optimal shipping and storage temperatures between production greenhouses and retail outlets could significantly improve flower longevity. Our flower longevity experiments were performed at temperatures from 14 to $29^{\circ} \mathrm{C}$, and our model estimated that the $\mathrm{T}_{\mathrm{b}}$ for flower longevity was $3.6^{\circ} \mathrm{C}$. However, previous studies have shown that potted $Z y$ gopetalum develop symptoms of chilling injury at temperatures $\leq 8{ }^{\circ} \mathrm{C}$ (unpublished data). Therefore, the optimal temperature for flower and inflorescence longevity is likely between 8 and $14{ }^{\circ} \mathrm{C}$, which agrees with temperatures recommended to maximize cut flower life of orchids (10 to $14{ }^{\circ} \mathrm{C}$; Sacalis, 1989,1993$)$.

In summary, these experiments suggest that

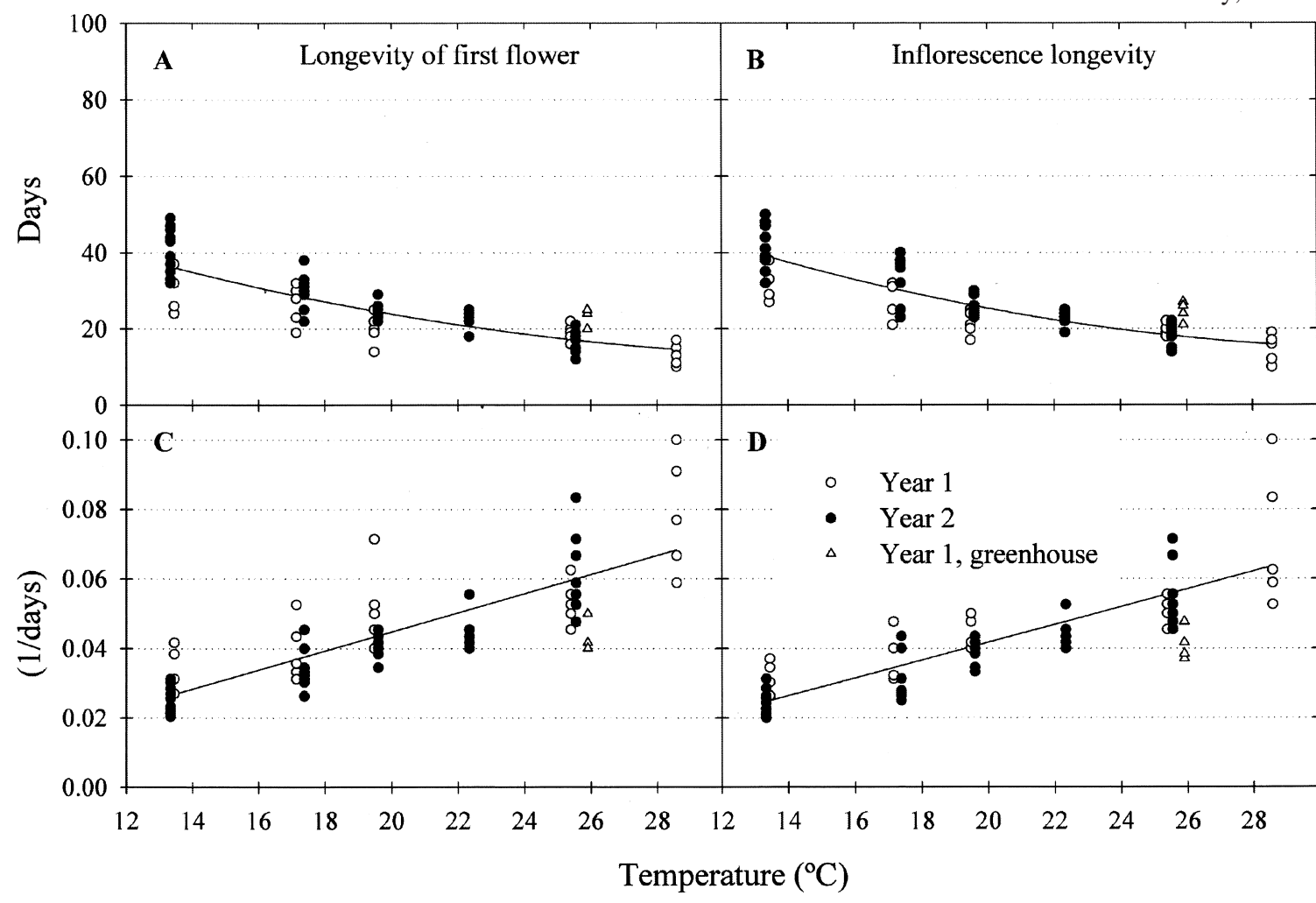
an optimal temperature for vegetative growth of Zygopetalum is between 20 and $25^{\circ} \mathrm{C}$, and further increases in temperature have little impact on the rate of leaf development.

Fig. 4. Influence of forcing temperature on longevity of the first open flower (A and $\mathbf{C}$ ) and inflorescence (B and $\mathbf{D})$ of Zygopetalum Redvale 'Fire Kiss'. Each symbol represents an individual plant. The solid lines represent the regression equation using pooled data for Years 1 and 2. Lines in $\mathbf{C}$ and $\mathbf{D}$ represent predicted values for the rate of progress (1/days) to the indicated developmental stage according to linear regression. Statistical analysis is presented in Table 2. 
For example, according to our model, plants grown at $23{ }^{\circ} \mathrm{C}$ developed one leaf about $2 \mathrm{~d}$ slower than plants grown at $26^{\circ} \mathrm{C}$. Following flower induction, a finish forcing temperature of 20 to $23^{\circ} \mathrm{C}$ is suggested for relatively rapid flower development and acceptable flower quality. However, temperature can be adjusted using our model to help meet specific finish dates. Flower and inflorescence longevity of Zygopetalum placed in the average home or office $\left(20^{\circ} \mathrm{C}\right)$ is estimated at $23 \mathrm{~d}$ if light and water are not limited.

\section{Literature Cited}

Fisher,P.R., J.H.Leith, and R.D. Heins. 1996. Modeling flower bud elongation in Easter lily (Lilium longiflorum Thunb.) in response to temperature. HortScience 31:349-352.

Hartley, G., T.A. Nell, R.T. Leonard, J.E. Barrett, and T.H. Boyle. 1995. Effects of interior light and temperature on longevity of Rhipsalidopsis.
Acta Hort. 405:164-169.

Healy, W.E. and H.F. Wilkins. 1984. Temperature effects on 'Nellie White' flower bud development. HortScience 19:843-844.

Hew, C.S. and J.W.H. Yong. 1997. The physiology of tropical orchids in relation to the industry. World Scientific, Singapore.

Ichihashi, S. 1997. Orchid production and research in Japan, p. 171-212. In: J. Arditti and A.M. Pridgeon (eds.). Orchid biology: Reviews and perspectives. vol. VII. Kluwer Academic Publishers, Great Britain.

Lopez, R.G., E.S. Runkle, R.D. Heins, and C.M. Whitman. 2003. Temperature and photoperiodic effects on growth and flowering of Zygopetalum Redvale 'Fire Kiss' orchids. Acta Hort. 624:155-162.

Rittershausen B. and W. Rittershausen. 2000. The practical encyclopedia of orchids: A complete guide to orchids and their cultivation. Anness Publishing Limited, New York.

Roberts, E.H. and R.J. Summerfield. 1987. Measurement and prediction of flowering in annual crops, p. 17-50. In: J.G. Atherton (ed.). Manipulation of flowering. Butterworths, London.

Robinson, K.A. 2002. Effects of temperature on the flower development rate and morphology of Phalaenopsis orchid. MS thesis. Mich. State Univ., East Lansing.

Rose, J. 1993. Zygopetalum. Amer. Orchid Soc. Bul. 62:733-734.

Rotor, G.B. 1952. Daylength and temperature in relation to growth and flowering of orchids. Cornell Univ. Agr. Expt. Sta. Bul. 885:3-47.

Sacalis, J.N. 1989. Fresh (cut) flowers for designs: postproduction guide I. Pfeifer Printing, Columbus, Ohio.

Sacalis, J.N. 1993. Cut flowers: Prolonging freshness. $2^{\text {nd }}$ ed. Ball Publishing, Batavia, Ill.

Sakanishi, Y., H. Imanishi, and G. Ishida. 1980. Effect of temperature on growth and flowering of Phalaenopsis amabilis. Bul. Univ. Osaka, Ser. B. Agriculture and Biology, Osaka (Prefecture) Daigaku. 32:1-9.

U.S. Department of Agriculture. 2003. Floriculture crops 2002 summary. Agr. Stat. Board, Wash., D.C. 